\title{
Evidence for Alteration of the Vitamin D-Endocrine System in Blacks
}

Norman H. Bell, Anne Greene, Sol Epstein, Mary Joan Oexmann, Sheryl Shaw, and Judith Shary

Veterans Administration Medical Center and Departments of Medicine and Pharmacology, Medical University of South Carolina, Charleston, South Carolina 29403; and Albert Einstein Medical Center, York and Tabor Roads, Philadelphia, Pennsylvania 19141

\begin{abstract}
As compared with values in white subjects, bone mass is known to be increased and urinary calcium to be diminished in black individuals. To evaluate the possibility that these changes are associated with alterations in the vitamin Dendocrine system, an investigation was performed in 12 black subjects, 7 men and 5 women, and 14 white subjects, 8 men and 6 women, ranging in age from 20 to $35 \mathrm{yr}$. All of them were hospitalized on a metabolic ward and were given a constant daily diet containing $400 \mathrm{mg}$ of calcium, $900 \mathrm{mg}$ of phosphorus, and 110 meq of sodium. Whereas mean serum calcium, ionized calcium, and phosphate were the same in the two groups, mean serum immunoreactive parathyroid hormone $(350 \pm 34$ vs. $225 \pm 26 \mathrm{pg} / \mathrm{ml}, P<0.01)$ and mean serum 1,25 dihydroxyvitamin D $\left(1,25(\mathrm{OH})_{2} \mathrm{D}\right)(41 \pm 3$ vs. $29 \pm 2 \mathrm{pg} / \mathrm{ml}, P$ $<0.01$ ) were significantly higher, and mean serum 25-hydroxyvitamin D (25-OHD) was significantly lower in the blacks than in the whites $(6 \pm 1$ vs. $20 \pm 2 \mathrm{ng} / \mathrm{ml}, P<0.001)$. Mean urinary sodium and $24-\mathrm{h}$ creatinine clearance were the same in the two groups, whereas mean urinary calcium was significantly lower $(101 \pm 14$ vs. $166 \pm 13 \mathrm{mg} / \mathrm{d}, P<0.01)$ and mean urinary cyclic AMP was significantly higher $(3.11 \pm 0.47$ vs. $1.84 \pm 0.25 \mathrm{nM} / \mathrm{dl}$ glomerular filtrate, $P<0.01$ ) in the blacks. Further, the blacks excreted an intravenous calcium load, 15 $\mathrm{mg} / \mathrm{kg}$ body weight, as efficiently as the whites $(49 \pm 3 \mathrm{vs}$. $53 \pm 3 \%$, NS). Mean serum Gla protein was lower in blacks than in whites $(14 \pm 2$ vs. $24 \pm 3 \mathrm{ng} / \mathrm{ml}, P<0.02)$, and increased significantly in both groups in response to $1,25(\mathrm{OH})_{2} \mathrm{D}_{3}, 4 \mu \mathrm{g} /$ $d$ for $4 \mathrm{~d}$. There was a blunted response of urinary calcium to $1,25(\mathrm{OH})_{2} \mathrm{D}_{3}$ in the blacks, and mean serum calcium did not change. The results indicate that alteration of the vitamin Dendocrine system with enhanced renal tubular reabsorption of calcium and increased circulating $1,25(\mathrm{OH})_{2} \mathrm{D}$ as a result of secondary hyperparathyroidism may contribute to the increased bone mass in blacks. Their low serum 25-OHD is attributed to diminished synthesis of vitamin $D$ in the skin because of increased pigment.
\end{abstract}

\section{Introduction}

Available evidence indicates that bone mass is increased in black as compared with white subjects $(1,2)$. Skeletal development of black children is advanced in comparison to that of white children, and black children exhibit greater body size through adolescence (3-6). Based on radiographic measure-

Dr. Bell is a Veterans Administration Medical Investigator. Address reprint requests to Dr. Bell, VA Medical Center, Charleston, SC 29403.

Received for publication 22 January 1985 and in revised form 29 April 1985.

The Journal of Clinical Investigation, Inc.

Volume 76, August 1985, 470-473 ments of metacarpal cortical area, blacks have a greater skeletal mass than whites from age 1-80 yr $(6,7)$. As compared with whites, blacks also have a lower urinary calcium (8). In view of these observations, we carried out studies to determine whether the increased bone mass and reduction in urinary calcium in blacks is associated with changes in the vitamin Dendocrine system.

\section{Methods}

26 normal subjects were studied. There were 12 blacks (seven men and five women) and 14 whites (eight men and six women) who ranged in age from 20 to $35 \mathrm{yr}$ of age. All of them were hospitalized in the General Clinical Research Center of the Medical University of South Carolina. They were given only distilled water to drink and a constant daily diet estimated to contain $400 \mathrm{mg}$ calcium, $900 \mathrm{mg}$ phosphate, $18 \mathrm{meq}$ magnesium, $110 \mathrm{meq}$ sodium, and $65 \mathrm{meq}$ potassium. Fasting blood samples were collected at intervals for measurement of serum calcium, ionized calcium, inorganic phosphate, magnesium, creatinine, Gla protein, 25-hydroxyvitamin D (25-OHD), 1,25-dihydroxyvitamin $\mathrm{D}\left(1,25(\mathrm{OH})_{2} \mathrm{D}\right)$, and immunoreactive parathyroid hormone (PTH), ${ }^{\prime}$ and 24-h urines were collected for measurement of calcium, inorganic phosphate, sodium, potassium, magnesium, creatinine, and cyclic adenosine $3^{\prime}, 5^{\prime}$-monophosphate (cAMP).

The study protocol was as follows. The first $2 \mathrm{~d}$ were a control period. On the third day, calcium gluconate, $15 \mathrm{mg}$ of calcium per kilogram body weight, was given intravenously over a period of $8 \mathrm{~h}$ in $5 \%$ dextrose in water beginning at 8:00 a.m. The fourth day was a control period. On days $5-8,1,25(\mathrm{OH})_{2} \mathrm{D}_{3}, 2 \mu \mathrm{g}$ by mouth every 12 $h$, was given on each of the $4 \mathrm{~d}$.

Serum and urinary calcium (9), inorganic phosphate (10), creatinine (11), and magnesium (12) were measured by automated methods. Serum-ionized calcium was determined with a solid state ion electrode. Urinary sodium and potassium were determined by flame photometer. Serum 25-OHD was measured in duplicate at two concentrations by competitive protein binding with vitamin D-deficient rat serum (13) after extraction with acetonitrile, washing with phosphate buffer, chromatography on C-18 Sep-Pak, and elution with acetonitrile (14). 25-OHD was separated from other vitamin D metabolites before the binding assay by chromatography on silica Sep-Pak and elution with hexane-propanol (96:4) (14). Serum $1,25(\mathrm{OH})_{2} \mathrm{D}$ was measured by the method of Reinhardt et al. (14). Serum immunoreactive PTH was measured by radioimmunoassay with a $\mathrm{COOH}$-terminal specific antibody from chicken 77125 at a dilution of 1:10,000 (15). Serum Gla protein was determined by radioimmunoassay (16). Urinary cAMP was measured by radioassay with a binding protein (17). Results are expressed as nanomolar per deciliter glomerular filtrate (GF) (18).

Statistical analyses were performed by standard methods for paired and nonpaired $t$ tests with an Apple Ile computer.

\section{Results}

The results are summarized in Tables I-IV and in Fig. 1. At the end of the 2-d control period, blacks showed significantly

1. Abbreviations used in this paper: GF, glomerular filtrate; PTH, parathyroid hormone. 

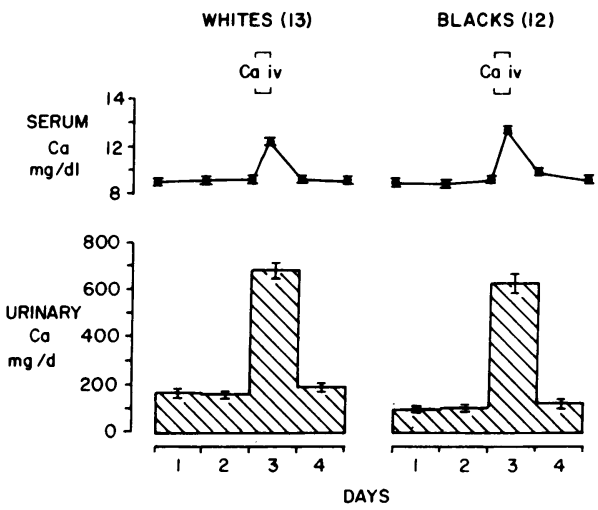

Figure 1. The effects of calcium infusion on serum and urinary calcium in normal white and black subjects. Calcium, $15 \mathrm{mg} / \mathrm{kg}$ body weight, was infused over a period of $8 \mathrm{~h}$ in 1 liter of $5 \%$ dextrose in water on day 3 . The amount of calcium infused averaged $1,001 \pm 34$ $\mathrm{mg}$ in the whites and $1,077 \pm 52 \mathrm{mg}$ in the blacks (NS). Mean body weight was $68 \pm 2 \mathrm{~kg}$ in the whites and $73 \pm 3 \mathrm{~kg}$ in the blacks (NS). The percentage of the load of calcium excreted was calculated by dividing the difference (milligrams) between the average of days 1 and 2 and day 3 of urinary calcium by the amount of calcium infused (milligrams). $\times 100$.

higher values for mean serum immunoreactive PTH and mean serum $1,25(\mathrm{OH})_{2} \mathrm{D}$ as compared with whites (Table I). Mean serum calcium, serum-ionized calcium, serum phosphate, and serum magnesium were the same in the two groups. Mean serum 25-OHD, obtained on day 1 of the study, was significantly lower in the blacks than in the whites. During the initial 2-d control period, mean urinary calcium, phosphate, potassium, and magnesium were significantly lower in the blacks, their mean urinary cAMP was significantly higher, and mean urinary sodium and creatinine clearance were the same in the two groups (Table II). Renal excretion of calcium after infusion of the ion, $15 \mathrm{mg}$ of calcium per kilogram of body weight, was the same in the two groups (Fig. 1). The mean excretion of the administered calcium was $49 \pm 3 \%$ in the blacks and $52 \pm 3 \%$ in the whites (NS). Mean serum calcium was the same in the two groups before infusion (Table I) and was significantly higher in the blacks than in the whites at the end of the infusion $(13.3 \pm 0.2$ vs. $12.2 \pm 0.1 \mathrm{mg} / \mathrm{dl}, P<0.001)$. Mean urinary cAMP declined significantly during the calcium infusion in both groups, from $3.11 \pm 0.47$ to $1.15 \pm 0.20 \mathrm{nM} / \mathrm{dl} \mathrm{GF}$ in the blacks $(P<0.01)$ and from $1.84 \pm 0.25$ to $1.14 \pm 0.19 \mathrm{nM} /$ dl GF in the whites $(P<0.05)$.

In response to $1,25(\mathrm{OH})_{2} \mathrm{D}_{3} 4 \mu \mathrm{g} / \mathrm{d}$ for $4 \mathrm{~d}$, mean serum calcium did not change (Table III), but mean urinary calcium increased in both groups (Table IV). Urinary calcium was consistently higher in the whites, and the increment in response to $1,25(\mathrm{OH})_{2} \mathrm{D}_{3}$ was greater in them. Mean serum phosphate increased significantly (Table III), and there was a transient increase on day 5 in urinary phosphate in response to $1,25(\mathrm{OH})_{2} \mathrm{D}_{3}$ in both groups (Table IV). Urinary phosphate was higher in the whites than in the blacks during treatment with $1,25(\mathrm{OH})_{2} \mathrm{D}_{3}$. Mean serum Gla protein was significantly lower in the blacks than in the whites before $1,25(\mathrm{OH})_{2} \mathrm{D}_{3}$, and increased significantly in response to $1,25(\mathrm{OH})_{2} \mathrm{D}_{3}$ in both groups (Table III). Urinary cAMP was reduced on the last day of $1,25(\mathrm{OH})_{2} \mathrm{D}_{3}$ administration as compared with the first two control days (Table II), averaging $1.50 \pm 0.29 \mathrm{nM} / \mathrm{dl}$ GF in the blacks and $1.10 \pm 0.23 \mathrm{nM} / \mathrm{dl}$ GF in the whites (NS).

There were no significant differences in any of the measurements between white men and white women and between black men and black women (data not shown).

\section{Discussion}

Our results provide evidence for secondary hyperparathyroidism in normal young black adult subjects. There were significant increases in mean serum immunoreactive PTH, urinary cAMP, and serum $1,25(\mathrm{OH})_{2} \mathrm{D}$. These changes occurred in the absence of any alterations in mean serum ionized and total calcium and serum phosphate. Further, serum Gla protein, a bone marker that varies directly with parathyroid status, which is elevated in patients with hyperparathyroidism and diminished in individuals with hypoparathyroidism (19), was lower in the blacks than in the whites despite the increased values for serum immunoreactive PTH in the blacks. Taken together, these results provide evidence for alteration in the vitamin Dendocrine system in blacks. The fact that serum Gla protein increased in response to $1,25(\mathrm{OH})_{2} \mathrm{D}_{3}$ in both the blacks and whites indicates that the skeleton is normally responsive to $1,25(\mathrm{OH})_{2} \mathrm{D}_{3}$ in blacks.

Our findings also indicate that reduced urinary calcium in blacks (8) results from secondary hyperparathyroidism. A calcium load, which produced hypercalcemia and caused comparable suppression of urinary cAMP in the blacks and whites, was excreted equally well by the two groups. Had the decrease in urinary calcium been caused by a renal tubular defect, there should have been a delay in the renal excretion of calcium in the blacks. This did not occur.

Mean serum 25-OHD was lower in the blacks than in the whites. This difference could result from feedback inhibition of hepatic synthesis of 25-OHD by the increased circulating

Table I. Serum Values in Normal Black and White Subjects

\begin{tabular}{|c|c|c|c|c|c|c|c|}
\hline Subjects & $\begin{array}{l}\text { Serum } \\
\text { calcium }\end{array}$ & $\begin{array}{l}\text { Serum } \\
\mathrm{Ca}^{2+}\end{array}$ & $\begin{array}{l}\text { Serum } \\
\text { phosphate }\end{array}$ & $\begin{array}{l}\text { Serum } \\
\text { magnesium }\end{array}$ & $\begin{array}{l}\text { Serum } \\
\text { iPTH* }\end{array}$ & $\begin{array}{l}\text { Serum } \\
25-O H D\end{array}$ & $\begin{array}{l}\text { Serum } \\
1,25(\mathrm{OH})_{2} \mathrm{D}\end{array}$ \\
\hline & $m g / d l$ & $m g / d l$ & $m g / d l$ & meq/liter & $p g / m l$ & $n g / m l$ & $p g / m l$ \\
\hline Black (12) & $9.0 \pm 0.1$ & $4.9 \pm 0.1$ & $3.9 \pm 0.1$ & $1.80 \pm 0.03$ & $350 \pm 34$ & $6 \pm 1$ & $41 \pm 3$ \\
\hline White (14) & $9.0 \pm 0.1$ & $4.8 \pm 0.1$ & $3.9 \pm 0.2$ & $1.85 \pm 0.04$ & $225 \pm 26$ & $20 \pm 2$ & $29 \pm 2$ \\
\hline$P$ value & NS & NS & NS & NS & $<0.01$ & $<0.001$ & $<0.01$ \\
\hline
\end{tabular}

Results are given as mean \pm SE. Figures in parentheses are the number of subjects. ${ }^{*}$ Serum immunoreactive PTH (iPTH) was measured in 9 blacks and 11 whites. 
Table II. Urinary Values in Normal Black and White Subjects

\begin{tabular}{llllllll}
\hline Subjects & $\begin{array}{l}\text { Urinary } \\
\text { calcium }\end{array}$ & $\begin{array}{l}\text { Urinary } \\
\text { phosphate }\end{array}$ & $\begin{array}{l}\text { Urinary } \\
\text { sodium }\end{array}$ & $\begin{array}{l}\text { Urinary } \\
\text { potassium }\end{array}$ & $\begin{array}{l}\text { Urinary } \\
\text { magnesium }\end{array}$ & $\begin{array}{l}\text { Creatinine } \\
\text { clearance }\end{array}$ \\
\hline & $m g / d$ & $m g / d$ & $m e q / d$ & meq/d & meq/d & nM/dl GF \\
Black (12) & $101 \pm 14$ & $688 \pm 44$ & $124 \pm 8$ & $40 \pm 2$ & $7.2 \pm 0.6$ & $3.11 \pm 0.47$ \\
White (14) & $166 \pm 13$ & $938 \pm 37$ & $124 \pm 8$ & $62 \pm 4$ & $9.2 \pm 0.4$ & $1.84 \pm 0.25$ \\
$P$ value & $<0.01$ & $<0.001$ & NS & $<0.001$ & $<0.02$ & $<0.01$ & $173 \pm 0$ \\
\hline
\end{tabular}

Results are given as mean $\pm \mathrm{SE}$ of the average urinary values of the first $2 \mathrm{~d}$ of the study. Figures in parentheses are the number of subjects.

$1,25(\mathrm{OH})_{2} \mathrm{D}$ in the blacks (20). However, regulation has not been demonstrated to occur at low concentrations of serum 25-OHD. Diminished dermal synthesis of vitamin D from 7dehydrocholesterol because of absorption of photons of light energy by skin pigment in the blacks is, therefore, a more likely explanation (21).

The question arises whether the secondary hyperparathyroidism in blacks results from factors that are intrinsic or from factors that are extrinsic to the skeleton. The increase in bone mass in blacks is attributed to increased muscle mass (2). The explanation that increased strain on the skeleton modifies the response to PTH in blacks is open to question, in view of the fact that skeletal mass is greater in men than in women, and the fact that there were no differences in values for serum immunoreactive PTH and serum $1,25(\mathrm{OH})_{2} \mathrm{D}$ in the men and women in the present study. Nevertheless, if increased strain on the skeleton does diminish its response to PTH, then biochemical changes similar to those we have observed in blacks might be present in obese subjects.

It was shown previously that serum immunoreactive PTH is abnormally increased in obese subjects, and that the values returned to the normal range with weight loss that was produced by intestinal bypass (22). Further, the weight loss and decrease in circulating immunoreactive PTH correlated with each other. Our preliminary studies show significant increases in mean serum immunoreactive PTH, serum $1,25(\mathrm{OH})_{2} \mathrm{D}$, and urinary cAMP, and significant decreases in mean serum 25-OHD and urinary calcium in obese as compared with nonobese white subjects (23). The values are similar to those obtained in nonobese blacks in the present study. We attribute the decrease in serum 25-OHD in obesity to inhibition of hepatic synthesis of the metabolite by elevated, circulating $1,25(\mathrm{OH})_{2} \mathrm{D}(20,23)$. The finding that reduced serum 25OHD returned to normal in a group of obese subjects after weight reduction produced by intestinal bypass (24) is consistent with correction of secondary hyperparathyroidism (22) and increased circulating $1,25(\mathrm{OH})_{2} \mathrm{D}$ by weight loss. Some studies (25), but not others (24), show increases in bone mass in obese subjects.

Several of our findings in the blacks remain to be elucidated. Their urinary phosphate, potassium, and magnesium were significantly decreased as compared with the whites. Reduction of urinary potassium in blacks was reported previously and may result from low plasma renin and aldosterone (26). It is unlikely that the reduction in urinary magnesium is related to secondary hyperparathyroidism, since renal handling of the ion is not altered in patients with hyperparathyroidism or hypoparathyroidism (27). The decrease in urinary phosphate in the blacks was not anticipated in view of the increases in serum immunoreactive PTH. It is likely that intestinal absorption of phosphate, potassium, and magnesium may be diminished in blacks as compared with whites by mechanisms yet to be determined.

It could be argued that the increases in serum PTH, serum $1,25(\mathrm{OH})_{2} \mathrm{D}$, and urinary cAMP, and the reduction in urinary calcium in the blacks results from diminished intestinal absorption of calcium. This we regard as unlikely, since a reduction in calcium absorption would eventually lead to a decrease instead of the well-documented increase in bone mass in blacks $(1,2)$. Also, our finding of a reduction rather than an increase in mean serum Gla protein in the blacks, despite increases in circulating PTH, is evidence for altered skeletal response to the hormone. Nevertheless, it will be important to compare calcium absorption and the response to exogenous PTH in blacks and whites.

Finally, demonstration that intestinal absorption of calcium is enhanced in blacks because of increased circulating $1,25(\mathrm{OH})_{2} \mathrm{D}$, the major determinant of intestinal absorption of calcium in man (28), would indicate that the vitamin Dendocrine system is ideally programmed to spare the skeleton.

Table III. Effects of $1,25(\mathrm{OH})_{2} D_{3}$ on Serum Calcium, Serum Phosphate, and Serum Gla Protein in Normal Black and White Subjects

\begin{tabular}{|c|c|c|c|c|c|c|}
\hline \multirow[b]{2}{*}{ Subjects } & \multicolumn{2}{|c|}{ Serum calcium } & \multicolumn{2}{|c|}{ Serum phosphate } & \multicolumn{2}{|c|}{ Serum Gla protein } \\
\hline & Control & $1,25(\mathrm{OH})_{2} \mathrm{D}_{3}$ & Control & $1,25(\mathrm{OH})_{2} \mathrm{D}_{3}$ & Control & $1,25(\mathrm{OH})_{2} \mathrm{D}_{3}$ \\
\hline & $m g / d l$ & $m g / d l$ & $m g / d l$ & $m g / d l$ & $n g / m l$ & $n g / m l$ \\
\hline Black (12) & $9.1 \pm 0.1$ & $9.4 \pm 0.1^{*}$ & $3.8 \pm 0.2$ & $4.2 \pm 0.1 \ddagger$ & $14 \pm 2$ & $22 \pm 3 \S$ \\
\hline White (14) & $9.0 \pm 0.1$ & $9.0 \pm 0.1$ & $3.7 \pm 0.2$ & $4.3 \pm 0.2 \S$ & $24 \pm 3$ & $32 \pm 3 \ddagger$ \\
\hline$P$ value & NS & NS & NS & NS & $<0.02$ & $<0.05$ \\
\hline
\end{tabular}

Results are given as mean \pm SE of values obtained before and after $1,25(\mathrm{OH})_{2} \mathrm{D}_{3}, 4 \mu \mathrm{g} / \mathrm{d}$. Figures in parentheses are the number of subjects.

* NS vs. mean control value. $\ddagger P<0.02$ vs. mean control value. $\S P<0.001$ vs. mean control value. 
Table IV. Effects of $1,25(\mathrm{OH})_{2} \mathrm{D}_{3}$ On Urinary Calcium and Phosphate in Normal Black and White Subjects

\begin{tabular}{|c|c|c|c|c|c|c|c|c|}
\hline \multirow[b]{2}{*}{ Subjects } & \multicolumn{4}{|c|}{ Urinary calcium } & \multicolumn{4}{|c|}{ Urinary phosphate } \\
\hline & Day 5 & Day 6 & Day 7 & Day 8 & Day 5 & Day 6 & Day 7 & Day 8 \\
\hline & $m g / d$ & $m g / d$ & $m g / d$ & $m g / d$ & $m g / d$ & $m g / d$ & $m g / d$ & $m g / d$ \\
\hline Black (12) & $130 \pm 14$ & $189 \pm 12$ & $220 \pm 18$ & $227 \pm 14$ & $895 \pm 64$ & $724 \pm 58$ & $683 \pm 32$ & $715 \pm 38$ \\
\hline White (14) & $228 \pm 18$ & $322 \pm 22$ & $351 \pm 27$ & $385 \pm 36$ & $950 \pm 44$ & $802 \pm 29$ & $798 \pm 29$ & $852 \pm 33$ \\
\hline$P$ value & $<0.001$ & $<0.001$ & $<0.001$ & $<0.001$ & NS & NS & $<0.02$ & $<0.02$ \\
\hline
\end{tabular}

Results are given as mean \pm SE. Figures in parentheses are the number of subjects. $1,25(\mathrm{OH})_{2} \mathrm{D}_{3}, 4 \mu \mathrm{g} / \mathrm{d}$, was given on each of the $4 \mathrm{~d}$.

Thus, increased circulating PTH in blacks would augment the intestinal absorption of calcium by increasing serum $1,25(\mathrm{OH})_{2} \mathrm{D}$, and would prevent urinary loss of calcium by enhancing the tubular reabsorption of the ion. Our central hypothesis, which is still to be proven, is that strain on the skeleton alters the vitamin D-endocrine system. In our view, changes in the regulation of the vitamin D-endocrine system in a given individual may determine in a major way whether bone mass will be increased or decreased and whether osteoporosis will ensue.

\section{Acknowledgments}

We thank Elizabeth Katko for expert secretarial assistance and the nursing, dietary, and laboratory staff of the General Clinical Research Center for their contributions.

This work was supported in part by the Veterans Administration and by grants MO1 RR 1070 (General Clinical Research Center) and AM 36066 from the U. S. Public Health Service.

\section{References}

1. Trotter, M., G. E. Broman, and R. R. Peterson. 1960. Densities of bones of white and negro skeletons. J. Bone Jt. Surg. Am. Vol. 42A: 50-58.

2. Cohn, S. H., C. Abesamis, S. Yasamura, J. F. Aloia, I. Zanzi, and K. J. Ellis. 1977. Comparative skeletal mass and radial bone mineral content in black and white women. Metab. Clin. Exp. 26: 171-178.

3. Garn, S. M., S. T. Sandusky, J. M. Nagy, and M. B. McCann 1972. Advanced skeletal development in low-income Negro children. J. Pediatr. 80:965-969.

4. Owen, G. M., and L. H. Lubin. 1973. Anthropometric differences between black and white preschool children. Am. J. Dis. Child. 126: 168-169.

5. Garn, S. M. 1973. Tendency toward greater stature in American black children. Am. J. Dis. Child. 126:164-166.

6. Garn, S. M., and D. C. Clark. 1975. Nutrition, growth, development and maturation: findings from the ten-state survey 1968-70. Pediatrics. 56:306-319.

7. Garn, S. M. 1975. Bone loss and aging. In Physiology and Pathology of Human Aging. R. Goldman, editor. Academic Press, Inc., New York. 39-57.

8. Modlin, M. 1967. Urinary calcium in normal adults and in patients with renal stones: an interracial study. Invest. Urol. 5:49-57.

9. Baginsky, E. S., S. S. Marie, W. L. Clark, and B. Zak. 1973. Direct microdetermination of calcium. Clin. Chim. Acta. 46:49-54.

10. Fiske, C. H., and Y. Subbarow. 1925. The colorimetric determination of phosphorus. J. Biol. Chem. 66:375-400.
11. Bartels, H., and M. Bohner. 1971. Eine mikromethode zur kreatinin bestimmung. Clin. Chem. Acta. 32:81-85.

12. Gindler, E. M., and D. A. Heth. 1971. Colorimetric determination with bound "Calgamite" of magnesium in human blood serum. Clin. Chem. 17:662.

13. Dorantes, L. M., S. B. Arnaud, and C. D. Arnaud. 1978. Importance of the isolation of 25 -hydroxyvitamin D before assay. $J$. Lab. Clin. Med. 91:791-796.

14. Reinhardt, T. A., R. L. Horst, J. W. Orf, and B. W. Hollis. 1984. A microassay for 1,25-dihydroxyvitamin $D$ not requiring high performance liquid chromatography: application to clinical studies. $J$. Clin. Endocrinol. Metab. 58:91-98.

15. Wiske, P. S., S. Epstein, N. H. Bell, S. F. Queener, J. Edmondson, and C. C. Johnston, Jr. 1979. Increases in immunoreactive parathyroid hormone with age. N. Engl. J. Med. 300:1419-1421.

16. Epstein, S., J. Poser, R. McClintock, C. C. Johnston, Jr., G. Bryce, and S. Hui. 1984. Differences in serum bone Gla protein with age and sex. Lancet. II:307-310.

17. Gilman, A. G. 1970. A protein binding assay for adenosine 3',5'-monophosphate. Proc. Natl. Acad. Sci. USA. 67:305-312.

18. Broadus, A. E., J. E. Mahaffey, F. C. Bartter, and R. M. Neer. 1977. Nephrogenous cyclic adenosine monophosphate as a parathyroid function test. J. Clin. Invest. 60:771-783.

19. Price, P. A., J. G. Parthemore, and L. J. Deftos. 1980. A new biochemical marker for bone metabolism. J. Clin. Invest. 66:878-883.

20. Bell, N. H., S. Shaw, and R. T. Turner. 1984. Evidence that 1,25-dihydroxyvitamin $D_{3}$ inhibits the hepatic production of 25hydroxyvitamin D in man. J. Clin. Invest. 74:1540-1544.

21. Clemens, T. L., J. A. Adams, S. L. Henderson, and M. F. Holick. 1982. Increased skin pigment reduces the capacity of the skin to synthesize vitamin D. Lancet. I:74-76.

22. Atkinson, R. L., W. T. Dahms, G. A. Brady, and A. A. Schwartz. 1978. Parathyroid hormone levels in obesity: effects of intestinal bypass surgery. Miner. Electrolyte Metab. 1:315-320.

23. Bell, N. H., S. Epstein, A. Greene, J. Shary, S. Shaw, and M. J. Oexmann. Evidence for alteration of the vitamin D-endocrine system in obese subjects. J. Clin. Invest. In press.

24. Teitelbaum, S. L., J. D. Halverson, M. Bates, L. Wise, and J. G. Haddad. 1977. Abnormalities of circulating 25-OH vitamin D after jejunal-ileal bypass for obesity. Ann. Intern. Med. 86:289-293.

25. Dalen, N., D. Hallberg, and B. Lamke. 1975. Bone mass in obese subjects. Acta Med. Scand. 197:353-355.

26. Luft, F. C., C. E. Grim, N. Fineberg, and M. C. Weinberger. 1979. Effects of volume expansion and contraction in normotensive whites, blacks, and subjects of different ages. Circulation. 59:643-650.

27. Rude, R. K., J. E. Bethune, and F. R. Singer. 1980. Renal tubular maximum for magnesium in normal, hyperparathyroid and hypoparathyroid man. J. Clin. Endocrinol. Metab. 51:1425-1431.

28. Gallagher, J. C., B. L. Riggs, J. Eisman, A. Hamstra, S. B. Arnaud, and H. F. DeLuca. 1979. Intestinal calcium absorption and serum vitamin D metabolites in normal subjects and osteoporotic patients: effect of age and dietary calcium. J. Clin. Invest. 64:729-736. 